\title{
11. ACOUSTIC PROPERTIES OF VOLCANICLASTIC SEDIMENTS RECOVERED FROM THE FLOOR OF THE PHILIPPINE SEA, DEEP SEA DRILLING PROJECT LEG 59
}

\author{
R.L. Carlson, Department of Geophysics and Geodynamics Research Program, \\ Texas A\&M University, College Station, Texas \\ and
}

N. I. Christensen and R. H. Wilkens, Department of Geological Sciences and Graduate Program in Geophysics, University of Washington, Seattle, Washington

\section{INTRODUCTION}

Pyroclastic and other sediments derived from volcanic terranes are prominent constituents of the sediment column in the central and eastern parts of the Philippine Sea (Fig. 1). On the Palau-Kyushu Ridge (Site 448), basement is overlain by over 100 meters of vitric-tuff deposits, which are overlain in turn by about 170 meters of nannofossil chalk and ooze. In contrast, thick accumulations of vitric tuff are overlain by minor accumulations of pelagic clay in the east-central Parece Vela Basin (Sites 53, 54, and 450), (Fischer, Heezen, et al., 1971), and almost 900 meters of vitric tuff, ash, and breccia overlie igneous basement at Site 451 on the adjacent West Mariana Ridge. The seismic velocities of these vitric tuffs at in situ pressures can be usefully applied in the interpretation of seismic-reflection data collected in this region.
For this report compressional-wave velocities have been measured in samples from DSDP Sites 447 (Hole $447 \mathrm{~A}), 448,450$, and 451 at hydrostatic confining pressures to $1.0 \mathrm{kbar}$. Of the 26 samples studied, 19 are from Site 451 . The set also includes 10 pairs $(20$ samples) cut parallel and perpendicular to bedding in order to test for velocity anisotropy, which has been observed in other deep-sea sediments (e.g., Boyce, 1976; Carlson and Christensen, 1977a).

With the exception of Sample 448-35-1, which is a nannofossil ooze, all of the samples in this study are volcaniclastic. Grain size varies from very fine to sand sized. A majority of the samples contain basaltic clasts, and euhedral volcanogenic plagioclase laths are ubiquitous. Also present in varying amounts are authigenic clays, which probably result from the degradation of volcanic glass shards. Many of the samples are well sorted and the clasts are generally well rounded, sug-

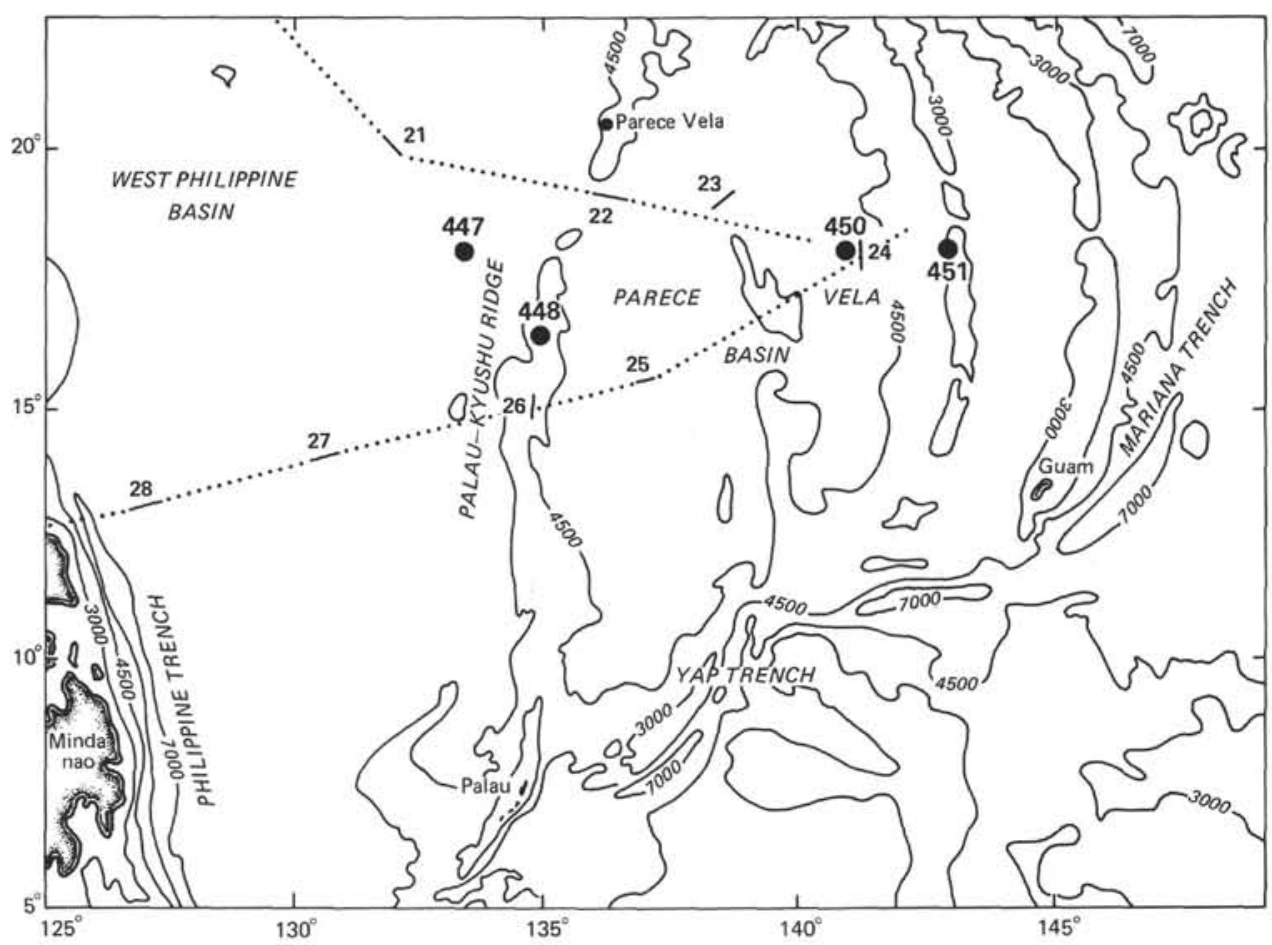

Figure 1. Locations of DSDP Sites $447,448,450,451$ seismic-refraction profiles and seismic sections. (Adapted from Murauchi et al., 1968.) 
gesting transport, probably in the form of turbidity flows. Samples lacking basalt clasts are finer grained and may represent wind-borne ash deposits.

\section{TECHNIQUES}

Samples in the form of "mini-cores," $2.54 \mathrm{~cm}$ in diameter, were sent to the shore laboratory in a partially water-saturated condition. Because the extent of water saturation is known to have a dramatic effect on compressional-wave velocities in rocks (e.g., Wyllie et al. 1958; Nur and Simmons, 1969; Christensen, 1970), the samples were brought to full saturation by soaking in fresh water for 7 to 10 days. The ends of the cores were subsequently trimmed and lapped smooth to form right circular cylinders 1.7 to $3.8 \mathrm{~cm}$ long.

The wet-bulk density values reported in Table 1 were measured using a Jolly balance. Sample densities were independently estimated from the weights and computed volumes of the cores. In most cases the densities determined by these two methods agree to within \pm 0.02 $\mathrm{g} / \mathrm{cm}^{3}$, but the Jolly-balance values are taken to be more reliable owing to the presence of chips and other irregularities in the cylinders.

Prior to the pressure runs, the cylinders were wrapped in two layers of 100-mesh screen and jacketed with copper foil to prevent the pressure medium from entering the rock. The screen provides voids into which pore water can escape from the sample at elevated confining pressures. In consequence, pore pressures are maintained at levels substantially lower than the pressure of the confining medium. Compressional-wave velocities were measured by the pulse-trans mission method (Birch, 1960) at confining pressures to $1.0 \mathrm{kbar}$. Depths of recovery, wet-bulk densities, and velocities are presented in Table 1.

\section{VELOCITY-DENSITY RELATIONS}

Wet-bulk densities range from 1.56 to $2.16 \mathrm{~g} / \mathrm{cm}^{3}$, and compressional-wave velocities measured at $0.1 \mathrm{kbar}$ range from 1.92 to $3.38 \mathrm{~km} / \mathrm{s}$. Velocity-density relations are illustrated in Figures 2 and 3. In Figure 2 the sediment densities and velocities measured at $0.2 \mathrm{kbar}$ are compared with data for DSPP basalts (Christensen, 1973a, 1973b, 1977; Christensen and Salisbury, 1972, 1973; Christensen et al., 1974; Carlson and Christensen,

Table 1. Summary of acoustic properties.

\begin{tabular}{|c|c|c|c|c|c|c|c|c|c|}
\hline \multirow{2}{*}{$\begin{array}{c}\text { Sample } \\
\text { (intervals in } \\
\mathrm{cm})\end{array}$} & \multirow{2}{*}{$\begin{array}{l}\text { Depth of } \\
\text { Recovery } \\
\text { (m) }\end{array}$} & \multirow{2}{*}{$\begin{array}{l}\text { Wet-Bulk } \\
\text { Density } \\
\text { (g/em })\end{array}$} & \multirow{2}{*}{$\begin{array}{l}\text { Propagation } \\
\text { Direction }\end{array}$} & \multicolumn{6}{|c|}{$\begin{array}{c}\text { Compressional-Wave Velocity }(\mathrm{km} / \mathrm{s}) \\
\text { versus Pressure (kbar) }\end{array}$} \\
\hline & & & & 0.1 & 0.2 & 0.4 & 0.6 & 0.8 & 1.0 \\
\hline $447 \mathrm{~A}-9-1(97-99)$ & 77 & 1.68 & h & 2,48 & 2.49 & 2.51 & 2.54 & 2.57 & 2.61 \\
\hline \multirow[t]{2}{*}{$447 \mathrm{~A}-9-1,100-101$} & & 1.74 & $\mathrm{v}$ & 2.55 & 2.56 & 2.58 & 2.62 & 2.67 & 2.70 \\
\hline & mean & 1.71 & - & 2.52 & 2.53 & 2.55 & 2.58 & 2.62 & 2.66 \\
\hline $447 \mathrm{~A} \cdot 12-3,4-6$ & 101 & 2.00 & h & 3.38 & 3.41 & 3.42 & 3.42 & 3.44 & 3.47 \\
\hline \multirow[t]{2}{*}{$447 \mathrm{~A} \cdot 12-3,0-4$} & & 1.97 & $\mathrm{v}$ & 3.19 & 3.21 & 3.23 & 3.24 & 3.26 & 3.28 \\
\hline & mean & 1.99 & - & 3.29 & 3.31 & 3.33 & 3.33 & 3.35 & 3.38 \\
\hline $448-35-1,71-74^{a}$ & 320 & 1.73 & $\mathrm{v}$ & 2.26 & 2.27 & 2.30 & 2.34 & 2.36 & 2.39 \\
\hline $450-25-1,28-30$ & 226 & 1.56 & $\mathrm{~h}$ & 1.97 & 1.99 & 2.03 & 2.07 & 2.10 & 2.12 \\
\hline \multirow[t]{2}{*}{$450-25-1,32-35$} & & 1.57 & $\mathrm{v}$ & 1.92 & 1.94 & 1.98 & 2.02 & 2.06 & 2.09 \\
\hline & mean & 1.57 & - & 1.95 & 1.97 & 2.01 & 2.05 & 2.08 & 2.11 \\
\hline $451-27-1,57-59$ & 243 & 1.87 & h & 2.85 & 2.87 & 2.91 & 2.92 & 2.96 & 2.98 \\
\hline $451-31-1,111-115$ & 281 & 2.16 & v & 3.25 & 3.31 & 3.37 & 3.40 & 3.42 & 3.45 \\
\hline $451-37-1,35-40$ & 338 & 1.92 & h & 2.83 & 2.87 & 2.95 & 3.02 & 3.08 & 3.14 \\
\hline \multirow[t]{2}{*}{$451-37 \cdot 1,35-40$} & & 1.92 & $\mathrm{v}$ & 2.85 & 2.89 & 3.01 & 3.12 & 3.17 & 3.18 \\
\hline & mean & 1.92 & - & 2.84 & 2.88 & 2.98 & 3.07 & 3.13 & 3.16 \\
\hline $451-46-3,6-8$ & 420 & 2.02 & h & 3.03 & 3.12 & 3.18 & 3.19 & 3.12 & 3.23 \\
\hline \multirow[t]{2}{*}{$451-46-3,10-13$} & & 1.96 & $\mathrm{v}$ & 2.97 & 3.01 & 3.04 & 3.08 & 3.23 & 3.28 \\
\hline & mean & 1.98 & - & 3.00 & 3.06 & 3.11 & 3.13 & 3.22 & 3.26 \\
\hline $451-54-4,81-87$ & 481 & 2.04 & h & 3.09 & 3.13 & 3.22 & 3.27 & 3.29 & 3.30 \\
\hline \multirow[t]{2}{*}{$451-54-4,81-87$} & & 1.96 & $\mathrm{v}$ & 2.76 & 2.84 & 2.99 & 3.09 & 3.16 & 3.20 \\
\hline & mean & 2.00 & - & 2.93 & 2.99 & 3.11 & 3.18 & 3.23 & 3.25 \\
\hline $451-60-2,101-104$ & 540 & 2.13 & $\mathrm{v}$ & 3.20 & 3.23 & 3.28 & 3.30 & 3.31 & 3.35 \\
\hline $451 \cdot 64-3,30-32$ & 578 & 1.87 & $\mathrm{~h}$ & 2.75 & 2.76 & 2.80 & 2.86 & 2.91 & 2.93 \\
\hline $451-66-4,142-145$ & 600 & 2.09 & $\because$ & 3.08 & 3,37 & 3.51 & 3.52 & 3.53 & 3.56 \\
\hline $451-70-1.27-3 i$ & 632 & 1.94 & h & 2.75 & 2.80 & 2.88 & 2.95 & 3.00 & 3.03 \\
\hline \multirow[t]{2}{*}{$451-70-1,32-35$} & & 1.94 & s & 2.80 & 2.86 & 2.94 & 3.00 & 3.14 & 3.20 \\
\hline & mean & 1.94 & - & 2.78 & 2.83 & 2.91 & 2.98 & 3.07 & 3.12 \\
\hline $451-79-1,42-48$ & 709 & 1.95 & $\mathrm{~h}$ & 2.64 & 2.67 & 2.72 & 2.76 & 2.81 & 2.83 \\
\hline \multirow[t]{2}{*}{$451-79-1,42-48$} & & 1.98 & $\mathrm{~s}$ & 2.90 & 2.94 & 2.99 & 3.00 & 3.00 & 3.00 \\
\hline & mean & 1.97 & - & 2.77 & 2.81 & 2.86 & 2.88 & 2.90 & 2.92 \\
\hline $451-86-1,86-88$ & 775 & 2.06 & $\mathrm{~h}$ & 2.62 & 2.67 & 2.72 & 2.74 & 2.78 & 2.82 \\
\hline \multirow[t]{2}{*}{$451-86-1,82-86$} & & 2.10 & $\checkmark$ & 2.60 & 2.66 & 2.76 & 2.83 & 2.88 & 2.92 \\
\hline & mean & 2.08 & - & 2.61 & 2.67 & 2.74 & 2.79 & 2.83 & 2.87 \\
\hline $451-93-2,124-126$ & 844 & 2.13 & h & 2.92 & 3.02 & 3.06 & 3.10 & 3.20 & 3.23 \\
\hline \multirow{2}{*}{$451-93-2,127-131$} & & 2.10 & $\mathrm{v}$ & 2.83 & 2.90 & 2.95 & 3.00 & 3.20 & 3.31 \\
\hline & mean & 2.12 & - & 2.88 & 2.96 & 3.01 & 3.05 & 3.20 & 3.27 \\
\hline
\end{tabular}

This sample is a nannofossil ooze: all others are volcaniclastic.

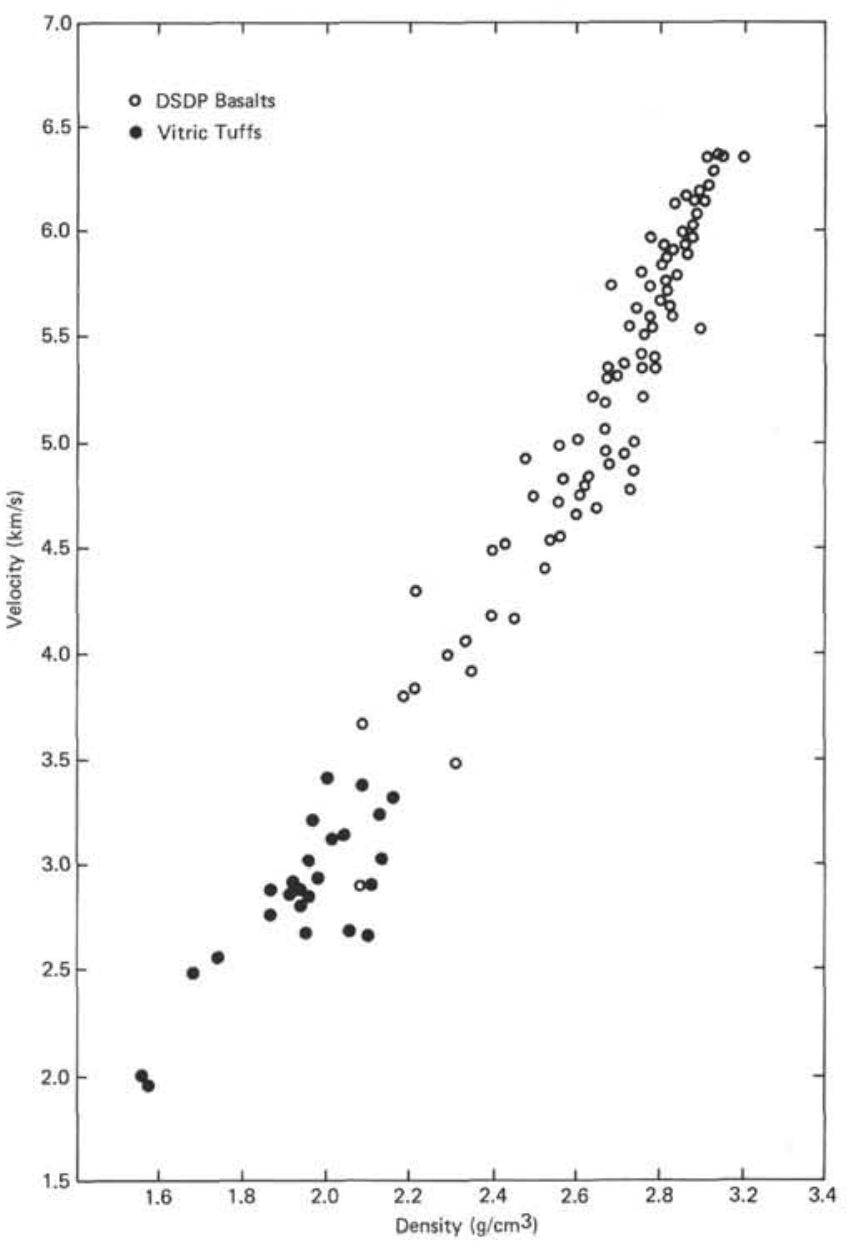

Figure 2. Compressional-wave velocity measured at 0.2 kbar versus density for Leg 59 sediments and DSDP basalts. (Sources of the basalt data are reported in text.)

1977b). Although densities and velocities of the tuffs are distinctly lower than those of the basalts, they lie on the same trend. This is not surprising, because the tuffs are essentially high-porosity examples of material having the same composition as the basalts. It is also clear that these volcanic sediments cannot be distinguished from highly weathered basalts on the basis of velocity and density data alone.

Figure 3 illustrates in more detail the relationship between density and velocity (measured at $0.1 \mathrm{kbar}$ ) for the vitric tuffs. With the exception of three pairs of samples, the velocity-density data follow a well-defined linear trend. Another important point is that much of the velocity anisotropy evident in Table 1 results from differences in wet-bulk density from one sample to another.

\section{DISCUSSION}

When sufficient data are available from one drilling site, variations of physical properties with depth can be assessed. This study includes samples from 12 levels between 243 and 844 meters at Site 451 on the West Mariana Ridge (see Table 1). Density- and velocity-depth relations for this site are illustrated in Figure 4. Though 


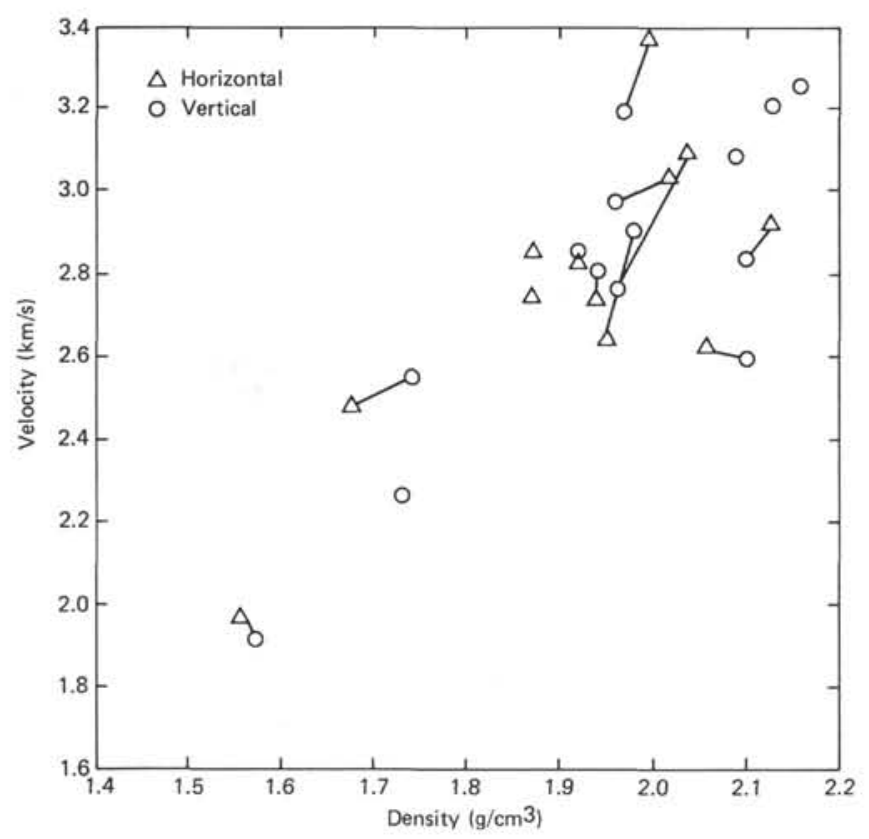

Figure 3. Compressional-wave velocity measured at 0.1 kbar versus density for Leg 59 sediments. (Lines connect samples in which velocities were measured parallel and perpendicular to bedding.)
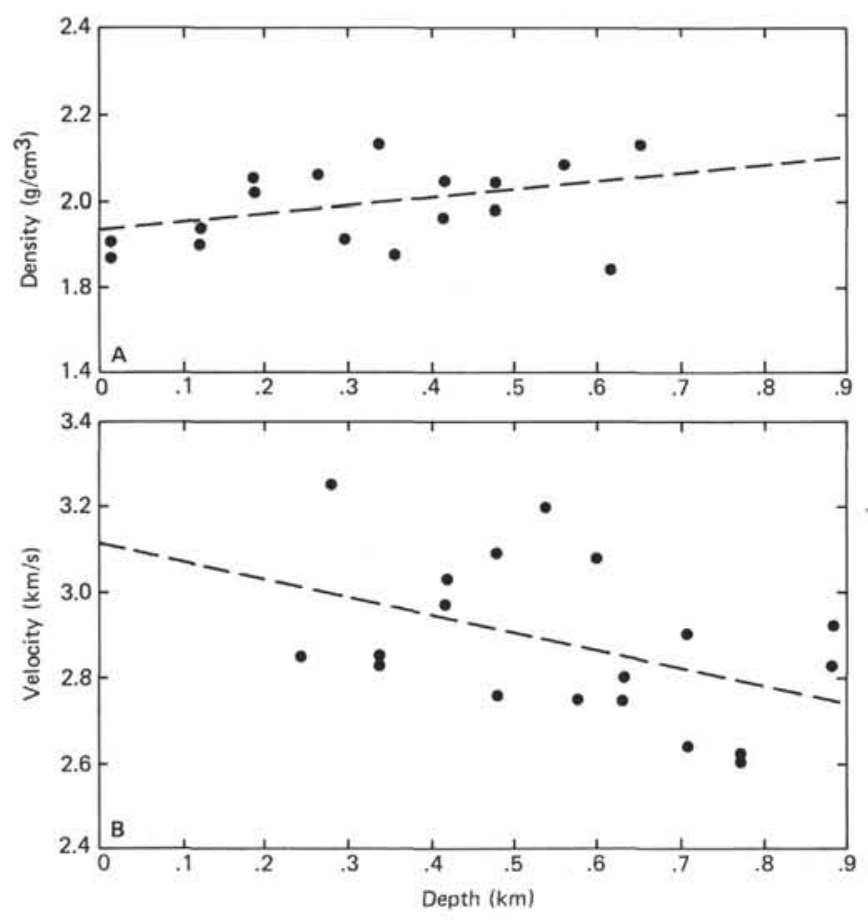

Figure 4. A. Wet-bulk density versus depth. B. Compressionalwave velocity versus depth for vitric tuffs from DSDP Site 451 . (Dashed lines represent regression relations; see Table 2 for regression parameters.)

the sediments are rather uniform in character, their properties are highly variable as evidenced by the scatter in the data. The nonuniform variation of density with depth (Figure 4A) suggests that the state of lithification (compaction and cementation) within the sediment col-
Table 2. Regression parameters.

$$
x=a+b z\left(z=\text { depth in } \mathrm{km} ; b=\frac{\delta x}{\delta z}\right)
$$

\begin{tabular}{cccccc}
\hline$x$ & $a$ & $b$ & $\sigma_{a}{ }^{\mathrm{a}}$ & $\sigma_{b}{ }^{\mathrm{a}}$ & $\begin{array}{c}\text { No. of } \\
\text { Samples }\end{array}$ \\
\hline $\mathrm{e} \mathrm{g} \mathrm{cm}{ }^{-3}$ & $1.91 \mathrm{~g} \mathrm{~cm}^{-3}$ & $+0.18 \mathrm{~g} \mathrm{~cm}^{-3} \mathrm{~km}^{-1}$ & 0.06 & 0.11 & 19 \\
$\mathrm{~V}_{p} \mathrm{~km} \mathrm{~s}^{-1}$ & $3.11 \mathrm{~km} \mathrm{~s}^{-1}$ & $-0.41 \mathrm{~km} \mathrm{~s}^{-1} \mathrm{~km}^{-1}$ & 0.12 & 0.21 & 19 \\
\hline $\mathrm{a}_{\sigma_{a} \text { and } \sigma_{b} \text { are standard deviations of the } z \text { intercept and slope, respectively. }}$
\end{tabular}

umn is also quite variable. The marked scatter in the compressional-wave velocity data (Figure 4B) reflects the variations in density and is probably enhanced by velocity anisotropy in some of the samples. The variability of density and velocity with depth at Site 451 may account for the transparent appearance of the tuffs on vertical reflection records.

The general trends in the density- and velocity-depth relations for Site 451 have been estimated by linear regression. Regression coefficients and pertinent statistics are summarized in Table 2 . As expected, there is a slight increase in density with increasing depth, whereas velocity shows a slight but statistically significant tendency to decrease with depth (Fig. 4). The sediment velocity profile at Site 451 would thus appear to be inverted. This result also appears to be inconsistent with the positive correlation between velocity and density shown in Figure 3. Figure 3, however, includes all of the data from this study, and the data from Site 451 show no significant trend when considered alone.

It is also interesting to compare laboratory data with the results of seismic surveys conducted in the vicinity of the drilling site. Murauchi et al. (1968) have conducted extensive refraction and wide-angle reflection surveys in the Philippine Sea (Fig. 1). Their results suggest that a "basement" layer having velocities of 4.5 to $6.0 \mathrm{~km} / \mathrm{s}$ is overlain by a layer up to $2 \mathrm{~km}$ thick, in which velocities range from 2.3 to $3.9 \mathrm{~km} / \mathrm{s}$. Specifically, Murauchi et al. (1968) found that the West Mariana Ridge is capped by a thick unit with velocities ranging from 2.7 to 3.5 $\mathrm{km} / \mathrm{s}$ at a location $6^{\circ}$ north of Site 451 . The range of velocities measured at $0.1 \mathrm{kbar}$ for samples from Site 451 is 2.60 to $3.25 \mathrm{~km} / \mathrm{s}$, which suggests that this unit consists of tuffs and related volcanic deposits, perhaps interbedded with flows. However, Christensen et al. (this volume) have found that the seismic velocities in breccias and vesicular basalts from Site 448 also fall in this range. Hence, correlations of lithology with velocity must be regarded as tenuous.

\section{ACKNOWLEDGMENTS}

We wish to thank R. J. Stewart for providing sample descriptions and J. Schultz for maintaining the high-pressure equipment for this study. We are also grateful to R. B. Scott and D. A. Fahlquist for reviewing the manuscript. This investigation was supported by the National Science Foundation under Grant No. OCE 7817919 and by Office of Naval Research contract N-00014-15-C-0502.

\section{REFERENCES}

Birch, F., 1960. The velocity of compressional waves in rocks to 10 kilobars. I. J. Geophys. Res., 65:1083-1102. 
Boyce, R. E., 1976. Sound velocity-density parameters of sediment and rock from DSDP drill Sites $315-318$ on the Line Islands Chain, Manihiki Plateau, and Tuamotu Ridge in the Pacific Ocean. In Schlanger, S. O., Jackson, E. D., et al., Init. Repts. DSDP, 33: Washington (U.S. Govt. Printing Office), 695-728.

Carlson, R. L., and Christensen, N. I., 1977a. Velocity anisotropy and physical properties of deep-sea sediments from the western South Atlantic. In Supko, P. R., Perch-Nielsen, K., et al., Init. Repts. DSDP, 39: Washington (U.S. Govt. Printing Office), 555-559.

1977b. Velocities, densities, and elastic constants of basalt and trachytic tuff, DSDP Leg 39. In Supko, P. R., Perch-Nielsen, K., et al., Init. Repts. DSDP, 39: Washington (U.S. Govt. Printing Office), 493-495.

Christensen, N. I., 1970. Compressional wave velocities in basalts from the Juan de Fuca Ridge. J. Geophys. Res., 75:2773-2775.

1973a. Compressional and shear wave velocities in basaltic rocks, Deep Sea Drilling Project, Leg 16. In van Andel, $\mathrm{Tj}$. H., Heath, G. R., et al., Init. Repts. DSDP, 16: Washington (U.S. Govt. Printing Office), 647-649.

1973b. Compressional and shear wave velocities and elastic module of basalts, Deep Sea Drilling Project, Leg 19. In Creager, J. S., Scholl, D. W., et al., Init. Repts. DSDP, 19: Washington (U.S. Govt. Printing Office), 657-659.
1977. Seismic velocities and elastic moduli of igneous and metamorphic rocks from the Indian Ocean. In Heirtzler, J. R., Bolli, H. M., Davies, T. A., et al. (Eds.), Indian Ocean Geology and Biostratigraphy: Washington, D.C. (Am. Geophys. Union), 279-300.

Christensen, N. I., Fountain, D. M., Carlson, R. L., et al., 1974. Velocities and elastic moduli of volcanic and sedimentary rocks recovered on DSDP Leg 25. In Simpson, E. S. W., Schlich, R., et al., Init. Repts. DSDP, 25: Washington (U.S. Govt. Printing Office), 357-360.

Christensen, N. I., and Salisbury, M. H., 1972. Sea floor spreading, progressive alteration of Layer 2 basalts, and associated changes in seismic velocities. Earth Planet. Sci. Lett., 15:367-375.

1973. Velocities, elastic moduli, and weathering-age relations for Pacific Layer 2 basalts. Earth Planet. Sci. Lett., 19: 461-470.

Fischer, A. G., Heezen, B. C., et al., 1971. Init. Repts. DSDP, 6: Washington (U.S. Govt. Printing Office)

Murauchi, S., Den, N., Asano, S., et al., 1968. Crustal structure of the Philippine Sea. J. Geophys. Res., 73:3143-3171.

Nur, A., and Simmons, G., 1969. The effect of saturation on velocity in low porosity rocks. Earth Planet. Sci. Lett., 7:183-193.

Wyllie, M. R. J., Gregory, A. R., and Gardner, G. G. F., 1958. An experimental investigation of factors affecting elastic wave velocities in porous media. Geophysics, 23:459-493. 